\title{
Influence of post weld heat treatment for weld joint of P355GH
}

\author{
Stawomir Parzych ${ }^{1, *}$, Rafat Dziurka ${ }^{2}$ \\ ${ }^{1}$ Cracow University of Technology, Institute of Materials Engineering, Faculty of Mechanical \\ Engineering, , 37 Jana Pawla II St., 31-864 Cracow, Poland \\ ${ }^{2}$ University of Science and Technology, Department of Physical Metallurgy \& Powder Metallurgy, \\ Faculty of Metals Engineering and Industrial Computer Science, 30 Mickiewicza St., 30-059 Cracow, \\ Poland
}

\begin{abstract}
From steel designed to work under pressure and exposed to high temperature apart from the good weldability, good mechanical properties are required. The guidelines set by the regulations require post welding heat treatment above $35 \mathrm{~mm}$ thick. An important factor affecting the microstructure and properties of the joint made of thick-walled elements is heat treatment after welding. All welding operations must be properly planned before performing welding work. Welding procedure specification (WPS) is a document describing these operations, it is essential for proper determining of basics in planning welding operations and quality control in welding. The purpose of this paper is to compare the properties of joints made by 121 welding method in combination with and without post welding heat treatment.
\end{abstract}

\section{Introduction}

From steel designed to work under pressure and exposed to high temperature apart from the good weldability, good mechanical properties are required. The guidelines set by the regulations require post welding heat treatment above $35 \mathrm{~mm}$ thick. An important factor affecting the microstructure and properties of the joint made of thick-walled elements is heat treatment after welding. All welding operations must be properly planned before performing welding work. Welding procedure specification (WPS) is a document describing these operations, it is essential for proper determining of basics in planning welding operations and quality control in welding. The purpose of this paper is to compare the properties of joints made by $135+121$ welding method in combination with and without post welding heat treatment. The MAG welding process (135) (Metal Active Gas) involves melting an edge of joined materials and a material of a consumable electrode by the heat of an electric arc in the shielding gases or gas mixtures [1]. The heat source in the MAG welding method is a welding arc glowing in the gas atmosphere between a consumable electrode and the weld material $[2,3]$. This method fully meets the requirements which are given to thick walled joints both in terms of technology and efficiency [5-8]. This welding process is currently. The SAW welding process (121) (Submerged arc welding) with high

\footnotetext{
* Corresponding author: slawomir.parzych@mech.pk.edu.pl
} 
heat input has been used to weld thick plates in order to reduce the number of passes and consequent increase of productivity in the shipbuilding and oil industries. Additional characteristics of SAW such as high penetration and relative ease to produce welds with good finishing and without discontinuities contribute to this process has being widely applied. However, the use of very high heat inputs leads to the formation of a large melting pool and large amount of liquid metal, and it submits the weld region to long-term thermal cycles with low cooling rates. This scenario contributes to the formation of thick solidification structures and, at the end of the cooling, results in a microstructure consisting mainly of grain boundary ferrite with low mechanical strength and large grain size [9].

\section{Materials used for testing}

P355GH steel was used as the basic material. It is a steel often used as a material for heat exchanger coats because its strength and plastic properties ensure no brittle fracture in the operating temperature range. According to the PN-CR ISO 15608 standard [11], P355GH steel belongs to group 1.2. It is a non-alloy quality steel, working under pressure and high temperature (up to about $400{ }^{\circ} \mathrm{C}$ ), whose yield strength for the smallest dimension range is $355 \mathrm{MPa}$. The chemical composition of the P355GH (Number 1.0473) steel is given in Table 1, mechanical properties in the standardized state are shown in Table 2.

Table 1. Chemical compositions of steel P355GH, \% mass [10].

\begin{tabular}{|c|c|c|c|c|c|c|c|c|}
\hline Symbol & $\mathrm{C}$ & $\mathbf{S i}$ & Mn & $\mathbf{P}$ & $\mathbf{S}$ & $\mathbf{N i}$ & Al & $\mathbf{T i}$ \\
\hline P355GH & 0.18 & 0.20 & 1.62 & 0.017 & 0.015 & 0.028 & 0.021 & 0.020 \\
\hline Symbol & Mo & $\mathrm{Al}$ & $\mathrm{Ti}$ & Mo & $\mathrm{Nb}$ & $\mathrm{V}$ & CEV & \\
\hline P355GH & 0.004 & 0.021 & 0.020 & 0.004 & 0.021 & 0.005 & 0.44 & \\
\hline
\end{tabular}

Table 2. Properties of P355GH steel in a standardized state [10].

\begin{tabular}{|c|c|c|c|c|c|c|}
\hline Symbol & $\begin{array}{c}\text { Normal } \\
\text { delivery } \\
\text { condition }\end{array}$ & $\begin{array}{c}\text { Produkt } \\
\text { thickness } \\
\mathbf{t}[\mathbf{m m}]\end{array}$ & $\begin{array}{c}\text { Yield } \\
\text { strength } \\
\mathbf{R}_{\mathrm{eH}}[\mathbf{M P a}]\end{array}$ & $\begin{array}{c}\text { Tensile } \\
\text { strength } \\
\mathbf{R}_{\mathbf{m}}[\mathbf{M P a}]\end{array}$ & $\begin{array}{c}\text { Elongation } \\
\mathbf{A}_{\mathbf{5}}[\mathbf{\%}]\end{array}$ & $\begin{array}{c}\text { Fracture } \\
\text { work } \\
\mathbf{K V}_{\mathbf{3 0}}[\mathbf{J}]\end{array}$ \\
\hline $\mathrm{P} 355 \mathrm{GH}$ & $+\mathrm{N}$ & 30 & 377 & 550 & 28 & 127 \\
\hline
\end{tabular}

\subsection{Examinations of welding technology}

In order to evaluate the welding technology, numerous tests were carried out on test joints (1 and 2), adopting acceptance criteria included in the qualification standard for the specification of the initial welding procedure by testing the welding technology in accordance with the PN-EN ISO 15614-1 standard [12]. The tests were carried out on test joints (1 and 2) prepared in accordance with the initial preliminary welding procedure specification (pWPS) for MAG method (131) and SAW method (121) with heat treatment No. 1. Combinations of MAG (131) and SAW methods (121) without heat treatment - No. 2 .

\subsubsection{Sample welded joint}

The welded test joint was prepared in accordance with the requirements of the PN-EN ISO 15614-1 [12] standard. The test joints used for the test were made of $300 \times 35 \mathrm{~mm}$ and $30 \mathrm{~mm}$ steel sheets of P355GH type steel. Both Joints (1 and 2) were made in the low 
position PA using the $\mathrm{X}$ bevel (Figure 1). The detailed data described in the specification of the initial welding procedure is shown in Figure 1 and Table 3.

a)

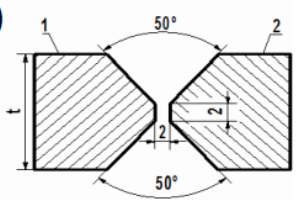

b) 1

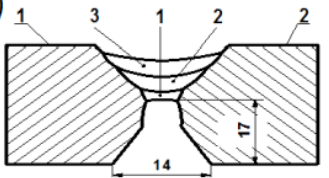

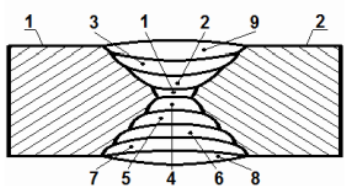

Fig. 1. A diagram of samples joint: a) welding preparation b) welding sequences

Table 3. Details of the MAG + SAW methods of welding.

\begin{tabular}{|c|c|c|c|c|c|c|c|}
\hline $\begin{array}{l}\text { Run } \\
\text { numbe } \\
\quad \mathbf{r}\end{array}$ & $\begin{array}{l}\text { Welding } \\
\text { process }\end{array}$ & $\begin{array}{l}\text { Size of filler } \\
\text { metal }\end{array}$ & $\begin{array}{c}\text { Curren } \\
\text { t A }\end{array}$ & $\begin{array}{c}\text { Voltage } \\
\mathbf{V}\end{array}$ & Polarity & $\begin{array}{c}\text { Wire feed } \\
\text { speed }\left(\mathrm{v}_{\mathrm{d}}\right) \\
{[\mathrm{cm} / \mathrm{min}]} \\
\text { Travel speed } \\
\left(\mathrm{v}_{\mathrm{p}}\right)[\mathrm{cm} / \mathrm{min}]\end{array}$ & $\begin{array}{c}\text { Heat } \\
\text { quantity } \\
{[\mathrm{kJ} / \mathrm{cm}]}\end{array}$ \\
\hline 1 & 135 & $\Phi 1.2$ & 205 & 23.7 & $\mathrm{DC}(+)$ & $\begin{array}{c}\mathrm{Vp}=28.6 \\
\mathrm{Vd}=31\end{array}$ & 8 \\
\hline 2 & 121 & $\Phi 3.0$ & 400 & 26 & $\mathrm{DC}(+)$ & $\mathrm{Vp}=34.1$ & 18 \\
\hline 3 & 121 & $\Phi 3.0$ & 400 & 28 & $\mathrm{DC}(+)$ & $\mathrm{Vp}=30$ & 22 \\
\hline 4 & 135 & $\Phi 1.2$ & 195 & 27.2 & $\mathrm{DC}(+)$ & $\begin{array}{l}\mathrm{Vp}=22.9 \\
\mathrm{Vd}=31\end{array}$ & 11 \\
\hline 5 & 135 & $\Phi 1.2$ & 230 & 28.3 & $\mathrm{DC}(+)$ & $\begin{array}{l}V p=25.6 \\
V d=31\end{array}$ & 12 \\
\hline 6 & 121 & $\Phi 3.0$ & 450 & 27.0 & $\mathrm{DC}(+)$ & $\mathrm{Vp}=30$ & 24 \\
\hline 7 & 121 & $\Phi 3.0$ & 500 & 25.0 & $\mathrm{DC}(+)$ & $\mathrm{Vp}=30$ & 25 \\
\hline 8 & 121 & $\Phi 3.0$ & 500 & 25.0 & $\mathrm{DC}(+)$ & $\mathrm{Vp}=30$ & 25 \\
\hline \multicolumn{8}{|c|}{ Wire (for method 135): G3Si1 according to EN ISO 14341-A (OK Autrod 12.51) } \\
\hline \multicolumn{8}{|c|}{ Shielding gas type: Ferromix -M21 according to PN-EN ISO 14175} \\
\hline \multicolumn{8}{|c|}{ Gas flow rate $[1 / \mathrm{m}]: 8-17$} \\
\hline \multicolumn{8}{|c|}{ Wire (for method 121): S2Si according PN-EN 756 ( OK Autrod 12.22) } \\
\hline \multicolumn{8}{|c|}{ Flux type: OK Flux 10.61- SA FB 1 65DC according to PN-EN ISO 14174.} \\
\hline \multicolumn{8}{|c|}{ Pre-heating temperature: $>10^{\circ} \mathrm{C}$} \\
\hline \multicolumn{8}{|c|}{ Interpass temperature: $\max 200^{\circ} \mathrm{C}$} \\
\hline \multicolumn{8}{|c|}{ Post welding heat treatment: sample nr 1: YES; sample nr 2: NO } \\
\hline
\end{tabular}

In the welding process for method 135, a manganese-silicon wire with a diameter of 1.2 $\mathrm{mm}$ was used. This wire is designed for fine-grained carbon-manganese steels and lowcarbon construction steels: G3Sil according to EN ISO 14341-A (OK Autrod 12.51). An M21 gas mixture $(82 \% \mathrm{Ar}+18 \% \mathrm{CO} 2)$ was used methods 121 wire with a diameter of 3 $\mathrm{mm}$. For the method 121, a copper wire with the addition of manganese with a diameter of $3 \mathrm{~mm}$ was used. This wire is intended for welding structural steel of high and medium strength. After the welding process, the joint 1 was heat treated after welding. A stress relief annealing was performed at $620^{\circ} \mathrm{C}$ for 2 hours. The essence of thermal stress relief is to lower the yield point or creep at elevated temperatures, and thus to allow plastic deformations to take place in those areas where the internal stress exceeds these limits. Relaxation annealing is aimed at:

1) invoking optimal relaxation of remaining (residual) stresses,

2) to restore ductility in brittle zones after welding.

\subsection{Examinations of a sample welded joint}


Samples for destructive testing were taken after obtaining positive results of successively done NDT on the sample joint including the tensile test, bending, impact strength, macroscopic examination, and hardness distribution. Appropriate standards of examination were agreed to do non-destructive testing as well as an assessment of joints was adopted, which are presented in table 4. Samples for destructive testing were collected in accordance with PN EN ISO 15614-1 [12].

Table 4. A scope of inspection and examination of sample joints according to the PN-EN ISO 156141 standard [15].

\begin{tabular}{|c|c|c|}
\hline Sample joint & Type of examination & Scope of inspection \\
\hline \multirow{4}{*}{$\begin{array}{c}\text { A single } \\
\text { butt joint } \\
\text { with a full } \\
\text { penetration }\end{array}$} & Visual testing & $100 \%$ \\
\cline { 2 - 3 } & Radiographic or ultrasonic testing & $100 \%$ \\
\cline { 2 - 3 } & Detecting surface cracks & $100 \%$ \\
\cline { 2 - 3 } & Transverse tensile test & 2 samples \\
\cline { 2 - 3 } & Transverse bending test & 4 samples \\
\cline { 2 - 3 } & Impact strength test & 2 required sets \\
\cline { 2 - 3 } & Hacroscopic examination & 1 sample \\
\cline { 2 - 3 } & Longitudinal weld tensile test & 1 sample \\
\hline
\end{tabular}

First of all, each sample joint was subjected to non-destructive testing to the full extent, i.e. visual testing (VT), magnetic powder testing (MT), ultrasonic testing (UT) and radiographic testing (RT). The number of research methods was increased in relation to the requirements of the PN-EN ISO 15614-1 standard [12] by the radiographic examination. All the examinations were taken 48 hours after the welding process. Quality level B of welded joints was accepted in accordance with the PN-EN ISO 5817 standard [16].

\section{Results}

After the visual inspection in samples 1 and 2 no welding incompatibilities were found. No floods, discontinuities, etc. were observed. The weld geometry was correct. After the ultrasound and penetration tests, no welding incompatibilities were found. The transverse stretching test, as well as the longitudinal stretching and the bending test for both joints (1 and 2), gave positive results. The tearing of the samples in the longitudinal stretching test occurred outside the weld and the tensile strength value was above the lower limit of the basic material value (table 5).

Table 5. List of test results from the tensile test of transverse samples.

\begin{tabular}{|c|c|c|c|c|c|c|}
\hline \multicolumn{7}{|c|}{ Sample no 1 } \\
\hline Sample no & $\mathbf{a}_{\mathbf{0}}[\mathbf{m m}]$ & $\mathbf{b}_{\mathbf{0}}[\mathbf{m m}]$ & $\mathbf{S}_{\mathbf{0}}\left[\mathbf{m m}^{2}\right]$ & $\mathbf{F}_{\mathbf{m}}[\mathbf{N}]$ & $\mathbf{R}_{\mathbf{m}}[\mathbf{M P a}]$ & Fracture \\
\hline 1-R1 & 25.0 & 25.0 & 625 & 344000 & 550 & $\begin{array}{c}\text { Base material/ } \\
\text { no defects }\end{array}$ \\
\hline 1-R2 & 25.0 & 25.0 & 625 & 344000 & 550 & $\begin{array}{c}\text { Base material/ } \\
\text { no defects }\end{array}$ \\
\hline \multicolumn{7}{|c|}{ Sample no 2 } \\
\hline Sample no & $\mathbf{a}_{\mathbf{0}}[\mathbf{m m}]$ & $\mathbf{b}_{\mathbf{0}}[\mathbf{m m}]$ & $\mathbf{S}_{\mathbf{0}}\left[\mathbf{m m}^{\mathbf{2}}\right]$ & $\mathbf{F}_{\mathbf{m}}[\mathbf{N}]$ & $\mathbf{R}_{\mathbf{m}}$ [MPa] & Fracture \\
\hline 2-R1 & 25.0 & 25.0 & 625 & 344000 & 550 & $\begin{array}{c}\text { Base material/ } \\
\text { no defects }\end{array}$ \\
\hline 2-R2 & 25.0 & 25.0 & 625 & 344000 & 550 & $\begin{array}{c}\text { Base material/ } \\
\text { no defects }\end{array}$ \\
\hline
\end{tabular}


The test results from the tensile test of longitudinal samples from welded joints are shown in table 6 . The samples broke beyond the strength value of the additional materials to be welded.

Table 6. List of test results from the tensile test of longitudinal samples from welded joints.

\begin{tabular}{|c|c|c|c|c|c|c|c|c|c|}
\hline \multicolumn{10}{|c|}{ Sample no 1 } \\
\hline Sample no & $\begin{array}{c}\mathbf{d}_{\mathbf{0}} \\
{[\mathbf{m m}]}\end{array}$ & $\begin{array}{c}\mathbf{S}_{\mathbf{0}} \\
{\left[\mathbf{m m}^{2}\right]}\end{array}$ & $\begin{array}{c}\mathbf{L}_{\mathbf{o}} \\
{[\mathbf{m m}]}\end{array}$ & $\begin{array}{c}\mathbf{L}_{\mathbf{u}} \\
{[\mathbf{m m}]}\end{array}$ & $\begin{array}{c}\mathbf{A}_{\mathbf{5}} \\
{[\mathbf{\%}]}\end{array}$ & $\begin{array}{c}\mathbf{F}_{\mathbf{e}} \\
{[\mathbf{N}]}\end{array}$ & $\begin{array}{c}\mathbf{R}_{\mathbf{e}} \\
{[\mathbf{M P a}]}\end{array}$ & $\begin{array}{c}\mathbf{F}_{\mathbf{m}} \\
{[\mathbf{N}]}\end{array}$ & $\begin{array}{c}\mathbf{R}_{\mathbf{m}} \\
{[\mathbf{M P a}]}\end{array}$ \\
\hline $1-R 1$ & 6.0 & 28.26 & 30 & 39 & 30 & 12500 & 442 & 16200 & 573 \\
\hline $1-R 2$ & 6.0 & 28.26 & 30 & 37.4 & 24,6 & 12400 & 439 & 16600 & 587 \\
\hline \multicolumn{10}{|c|}{ Sample no 2 } \\
\hline Notes: Breakthroughs of plastic samples, without visible discrepancies \\
\hline Sample no & $\begin{array}{c}\mathbf{d}_{\mathbf{0}} \\
{[\mathbf{m m}]}\end{array}$ & $\begin{array}{c}\mathbf{S}_{\mathbf{0}} \\
{\left[\mathbf{m m}^{2}\right]}\end{array}$ & $\begin{array}{c}\mathbf{L}_{\mathbf{o}} \\
{[\mathbf{m m}]}\end{array}$ & $\begin{array}{c}\mathbf{L}_{\mathbf{u}} \\
{[\mathbf{m m}]}\end{array}$ & $\mathbf{A}_{\mathbf{5}}[\mathbf{\%}]$ & $\mathbf{F}_{\mathbf{e}}[\mathbf{N}]$ & $\begin{array}{c}\mathbf{R}_{\mathbf{e}} \\
{[\mathbf{M P a}]}\end{array}$ & $\mathbf{F}_{\mathbf{m}}[\mathbf{N}]$ & $\mathbf{R}_{\mathbf{m}}[\mathbf{M P a}]$ \\
\hline 2-R1 & 6.0 & 28.26 & 30 & 37.2 & 24 & 11200 & 396 & 15300 & 541 \\
\hline 2-R2 & 6.0 & 28.26 & 30 & 36.5 & 21.6 & 11500 & 407 & 15100 & 534 \\
\hline \multicolumn{10}{|c|}{ Notes: Breakthroughs of plastic samples, without visible discrepancies } \\
\hline
\end{tabular}

After bending tests on $U$, no welding inconsistencies were found in the samples. There were no tears affecting the properties of the connector (table 7).

Table 7. List of test results for weld bending test.

\begin{tabular}{|c|c|c|c|c|c|}
\hline \multicolumn{7}{|c|}{ Sample no 1 } \\
\hline Sample no & $\begin{array}{c}\mathbf{a}_{\mathbf{0}} \\
{[\mathbf{m m}]}\end{array}$ & $\begin{array}{c}\mathbf{b}_{\mathbf{0}} \\
{[\mathbf{m m}]}\end{array}$ & $\begin{array}{c}\text { surface } \\
\text { stretched }\end{array}$ & $\begin{array}{c}\text { Bending } \\
\text { angle }\end{array}$ & $\begin{array}{c}\text { Evaluation of the surface of the } \\
\text { place of rupture }\end{array}$ \\
\hline 1-SBB1 & 16.0 & 30.0 & $\begin{array}{c}\text { cross-section of } \\
\text { the weld }\end{array}$ & $180^{\circ}$ & without defects \\
\hline 1-SBB2 & 16.0 & 30.0 & $\begin{array}{c}\text { cross-section of } \\
\text { the weld }\end{array}$ & $180^{\circ}$ & without defects \\
\hline 1-SBB3 & 16.0 & 30.0 & $\begin{array}{c}\text { cross-section of } \\
\text { the weld }\end{array}$ & $180^{\circ}$ & without defects \\
\hline 1-SBB4 & 16.0 & 30.0 & $\begin{array}{c}\text { cross-section of } \\
\text { the weld }\end{array}$ & $180^{\circ}$ & without defects \\
\hline Sample no & $\begin{array}{c}\mathbf{a}_{\mathbf{0}} \\
{[\mathbf{m m}]}\end{array}$ & $\begin{array}{c}\mathbf{b}_{\mathbf{0}} \\
{[\mathbf{m m}]}\end{array}$ & $\begin{array}{c}\text { Sample no 2 } \\
\text { surface } \\
\text { stretched }\end{array}$ & $\begin{array}{c}\text { Bending } \\
\text { angle }\end{array}$ & $\begin{array}{c}\text { Evaluation of the surface of the } \\
\text { place of rupture }\end{array}$ \\
\hline 2-SBB1 & 16.0 & 30.0 & $\begin{array}{c}\text { cross-section of } \\
\text { the weld }\end{array}$ & $180^{\circ}$ & without defects \\
\hline 2-SBB2 & 16.0 & 30.0 & $\begin{array}{c}\text { cross-section of } \\
\text { the weld }\end{array}$ & $180^{\circ}$ & without defects \\
\hline 2-SBB3 & 16.0 & 30.0 & $\begin{array}{c}\text { cross-section of } \\
\text { the weld }\end{array}$ & $180^{\circ}$ & without defects \\
\hline 2-SBB4 & 16.0 & 30.0 & $\begin{array}{c}\text { cross-section of } \\
\text { the weld }\end{array}$ & $180^{\circ}$ & \multicolumn{2}{c}{} \\
\hline
\end{tabular}

Impact tests were performed at $-30^{\circ} \mathrm{C}$, regardless of the test site (HAZ, weld) all samples meet the required minimum, i.e. $27 \mathrm{~J}$ (table 8). After macroscopy, a hardness test was carried out in accordance with the PN-EN ISO 6507-1: 2007 standard. The measurements of weld joint hardness are below $380 \mathrm{HV} 10$ for non-heat treated materials and $320 \mathrm{HV} 10$ for heat treated materials. The results are presented in diagrams (Figures 2 and 3 ). 
Table 8. List of test results for impact test of welded joints.

\begin{tabular}{|c|c|c|c|c|c|c|c|c|}
\hline \multicolumn{10}{|c|}{ Sample no 1 } \\
\hline Sample no & $\begin{array}{c}\text { Sample } \\
\text { type }\end{array}$ & $\begin{array}{c}\mathbf{a}_{\mathbf{0}} \\
{[\mathbf{m m}]}\end{array}$ & $\begin{array}{c}\mathbf{b}_{\mathbf{0}} \\
{[\mathbf{m m}]}\end{array}$ & $\begin{array}{c}\mathbf{h}_{\mathbf{0}} \\
{[\mathbf{m m}]}\end{array}$ & $\mathbf{S}_{\mathbf{0}}\left[\mathbf{c m}^{2}\right]$ & $\begin{array}{c}\mathbf{K V} \\
{[\mathbf{J}]}\end{array}$ & $\begin{array}{c}\mathbf{K C V} \\
{\left[\mathbf{J} / \mathbf{c m}^{2}\right]}\end{array}$ & $\begin{array}{c}\text { Notch notch } \\
\text { location }\end{array}$ \\
\hline $1-1$ & VHT & 10.0 & 10.0 & 8.0 & 0.8 & 186 & 233 & HAZ \\
\hline $1-2$ & VHT & 10.0 & 10.0 & 8.0 & 0.8 & 210 & 263 & HAZ \\
\hline $1-3$ & VHT & 10.0 & 10.0 & 8.0 & 0.8 & 182 & 228 & HAZ \\
\hline $1-4$ & VWT & 10.0 & 10.0 & 8.0 & 0.8 & 161 & 201 & WELD \\
\hline $1-5$ & VWT & 10.0 & 10.0 & 8.0 & 0.8 & 165 & 206 & WELD \\
\hline $1-6$ & VWT & 10.0 & 10.0 & 8.0 & 0.8 & 169 & 211 & WELD \\
\hline \multicolumn{7}{|c|}{ Sample no 2 } \\
\hline Sample no & $\begin{array}{c}\text { Sample } \\
\text { type }\end{array}$ & $\begin{array}{c}\mathbf{a}_{\mathbf{0}} \\
{[\mathbf{m m}]}\end{array}$ & $\begin{array}{c}\mathbf{b}_{\mathbf{0}} \\
{[\mathbf{m m}]}\end{array}$ & $\begin{array}{c}\mathbf{h}_{\mathbf{0}} \\
{[\mathbf{m m}]}\end{array}$ & $\begin{array}{c}\mathbf{S}_{\mathbf{0}} \\
{\left[\mathbf{c m}^{2}\right]}\end{array}$ & $\begin{array}{c}\text { KV } \\
{[\mathbf{J}]}\end{array}$ & $\begin{array}{c}\text { KCV } \\
{\left[\mathbf{J} / \mathbf{c m}^{2}\right]}\end{array}$ & $\begin{array}{c}\text { Notch notch } \\
\text { location }\end{array}$ \\
\hline $2-1$ & VHT & 10.0 & 10.0 & 8.0 & 0.8 & 206 & 258 & HAZ \\
\hline $2-2$ & VHT & 10.0 & 10.0 & 8.0 & 0.8 & 200 & 250 & HAZ \\
\hline $2-3$ & VHT & 10.0 & 10.0 & 8.0 & 0.8 & 237 & 296 & HAZ \\
\hline $2-4$ & VWT & 10.0 & 10.0 & 8.0 & 0.8 & 168 & 210 & WELD \\
\hline $2-5$ & VWT & 10.0 & 10.0 & 8.0 & 0.8 & 41 & 52 & WELD \\
\hline $2-6$ & VWT & 10.0 & 10.0 & 8.0 & 0.8 & 68 & 85 & WELD \\
\hline
\end{tabular}

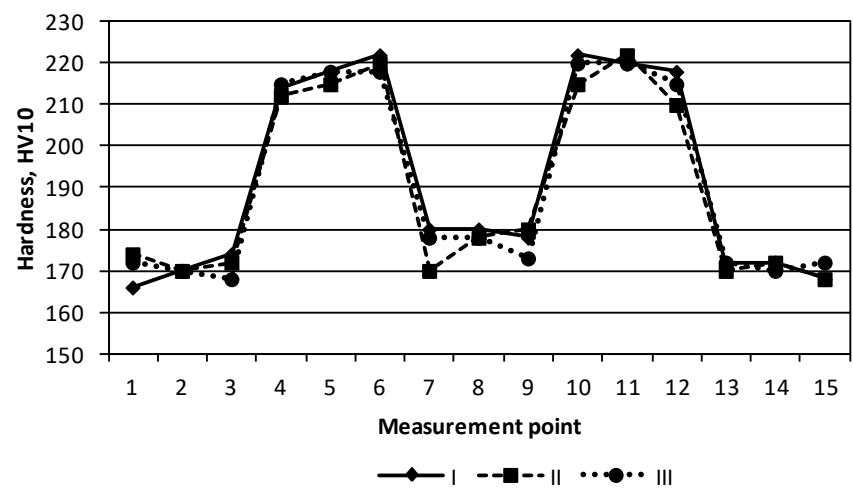

Fig. 2. Hardness distribution on the joint section 1 with post welding heat treatment.

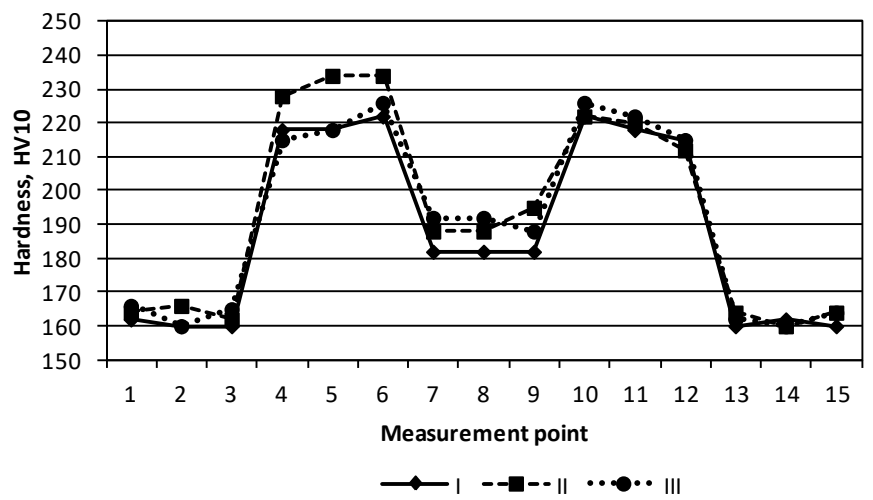

Fig. 3. Hardness distribution on the joint section 2 with post welding heat treatment.

In the final stage, microstructure was examined using a light microscope. Figures 4 and 5 show the microstructure of joint 1 and 2. Figures 4 and 5a show the microstructure of the base material consisting of a ferrite and perlite band structure. The HAZ microstructure 
with a coarse structure is shown in Figures $4 \mathrm{~b}$ and $5 \mathrm{~b}$. Fusion lines are shown in figures $4 \mathrm{c}$ and 5c. Welding microstructure consisting of Widmanstätten ferrite and fine-plate ferrite is shown in Figures $4 \mathrm{~d}$ and $5 \mathrm{~d}$.

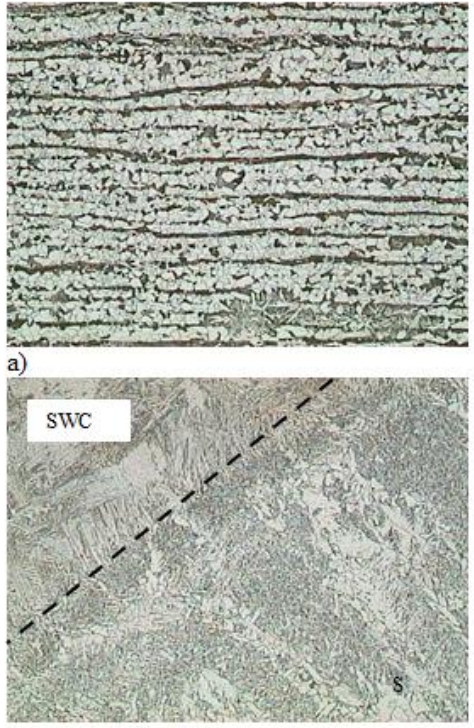

c)

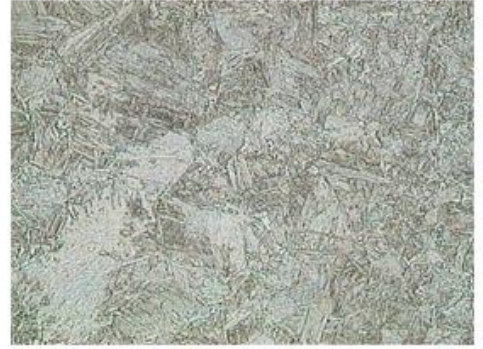

b)

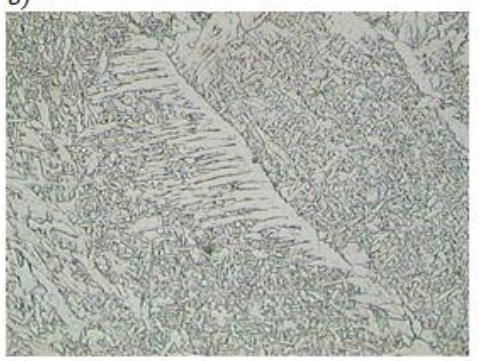

d)

Fig. 4. Welded joint microstructure, sample 1 (with pwht): a) base material, b) heat affected zone, c) fusion line, d) weld.

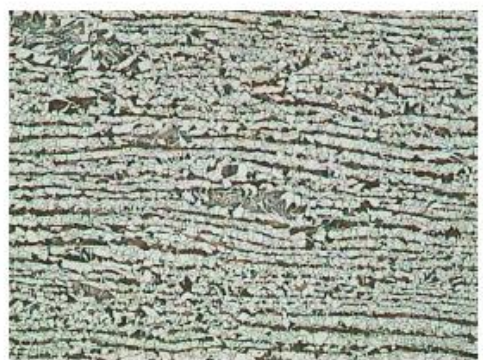

a)

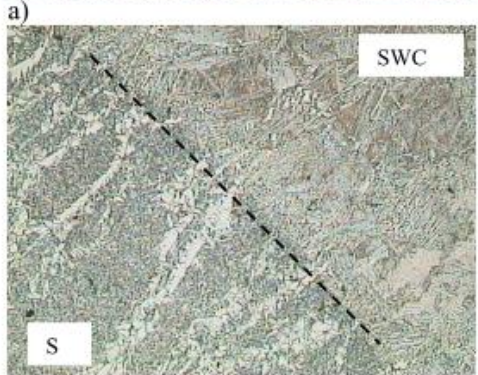

c)

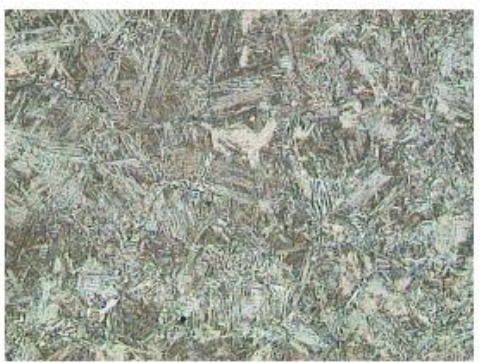

b)

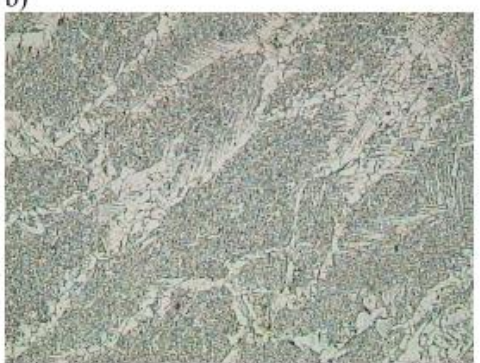

d)

Fig. 5. Welded joint microstructure, sample 1 (without pwht): a) base material, b) heat affected zone, c) fusion line, d) weld.

\section{Summary}


The welding procedure qualification record is carried out to check whether the factory has the appropriate qualifications to carry out welding work based on the applicable technological instructions and to confirm that welded joints comply with the requirements of the recipients in accordance with these instructions. All destructive and non-destructive tests confirmed the correctness of the welded joint. In addition, they confirmed the appropriate selection of welding materials. The applied heat treatment after welding improved the mechanical properties of the joint obtained. In the presented work, a welded joint made of steel of the P355GH grade has been tested. On the basis of tests determined by the UDT inspectorate, it was possible to verify the correctness of the parameters used during welding and the appropriate selection of welding materials.

The following conclusions can be drawn from the conducted conclusions:

1. The results of the tests performed on the test joints meet the requirements set in the standards, which is the basis for qualifying WPQR welding technology. The macroscopic tests showed the correct construction of the joint,

2. Microscopic examination did not show any internal discrepancies and joint structures are typical for this type of material,

3. Post welding heat treatment did not cause any significant changes in the test results due to the fact that UDT technical conditions require heat treatment to be welded with a thickness exceeding $36 \mathrm{~mm}$,

4. Post welding heat treatment did not cause any significant changes in the test results. It only caused a reduction of welding stresses in the joint zone.

\section{References}

1. PN-EN ISO 4063:2011

2. Praca zbiorowa; Poradnik inżyniera-Spawalnictwo tom II (WNT, Warszawa, 2005)

3. B. Pierożek, J. Lassociński, Spawanie tukowe stali w osłonach gazowych (WNT, Warszawa, 1987)

4. R. Krawczyk, Biuletyn Instytutu Spawalnictwa, 4 (2014)

5. PN-EN 1011-2:2008

6. PN-EN 10025-2:2008

7. J. Brózda, Stale konstrukcyjne i ich spawalność (Instytut Spawalnictwa, Gliwice, 2009)

8. R. Kaczmarek, R. Krawczyk, Przegląd Spawalnictwa, 86, 7 (2014)

9. L.H.S. Barbosa, P.J. Modenesi, L.B. Godefroid, A.R. Arias, Inter. J. Fatigue 119 (2019)

10. Świadectwo odbioru wytwórcy 3,1 ; blacha t30-P355GH

11. PN-CR ISO 15608:2002

12. PN-EN ISO 15614-1:2008 